\title{
Movimento da Legalidade (1961): resgatando o protagonismo de Mauro Borges
}

Tereza Cristina Pires Favaro*

Resumo: O objetivo desta comunicação é resgatar o protagonismo do Governador Mauro Borges no Movimento da Legalidade. Com a renúncia de Jânio Quadros, em 1961, os ministros militares tentaram impedir a posse de João Goulart, o que desencadeou uma ampla mobilização, dentro e fora do Congresso, com vistas a assegurar a ordem Constitucional. Inicialmente, dois governadores - Mauro Borges (GO) e Leonel Brizola (RS) - insurgiram-se contra o golpe e se colocaram, em seus estados, dispostos a resistir pacífica ou militarmente, se fosse o caso, até as últimas consequências, em defesa da Constituição. Isso leva a deflagrar o Movimento da Legalidade. A participação de Mauro Borges foi expressiva; com larga experiência em estratégias militares, o qual elaborou um plano minucioso e tático, inclusive de logística, aventando a possibilidade de um confronto armado contra as forças golpistas. Face às pressões, como saída conciliatória, instituiu-se o parlamentarismo, e João Goulart toma posse como presidente do Brasil (1961). No entanto, os desdobramentos políticos levam Mauro Borges a apoiar o golpe que levou à deposição de João Goulart do poder, em 1964.

Palavras-chave: Golpe. Militares. Resistência. Legalidade. Democracia.

* Doutoranda Tereza Cristina Pires Favaro, Programa de Pós-Graduação em História/UFG. E-mail: cristina_gyn@hotmail.com. Endereço institucional: Coordenação de Desenvolvimento de Pessoas, Hospital das Clínicas/UFG, $1^{\text {a }}$ Avenida, n545, Setor Leste Universitário, Goiânia, Goiás (CEP: 74605-020) 
O Movimento da Legalidade, deflagrado no Brasil em 1961, completados, portanto, 50 anos, foi um acontecimento da recente história política brasileira. Ocorreu em defesa da Constituição e teve como protagonistas dois governadores de Estado, Leonel de Moura Brizola, do Partido Trabalhista Brasileiro (PTB/RS) e Mauro Borges Teixeira, do Partido Social Democrático (PSD/GO). Até o presente e as pesquisas, vem enfatizando a participação de Leonel Brizola. O objetivo deste artigo é resgatar o protagonismo do governador de Goiás Mauro Borges, tendo em vista que a sua participação no Movimento é muito pouco abordada, quase sempre restrita ao exgovernador Leonel Brizola (RS).

Após uma efêmera passagem de sete meses pela presidência da República, Jânio Quadros renunciou ao cargo em 1961. Para Dreifuss (1981), seu governo expressou uma nova relação das forças sociais e grupos econômicos de poder em ascensão, e a direção política aproximava dos objetivos das classes empresariais. No entanto, um legado de problemas atingiu seu governo, a saber, uma inflação incontrolável, estagnação agrária, dificuldades na balança de pagamento, além da exaustão do mercado de consumo de bens duráveis, que favorecia a classe média alta, aliadas às inadequações burocráticas. Esses fatores obstaculizaram o crescimento distributivo esperado pelas forças populares, bem como a execução de um programa de reformas exigidas pela grande comunidade industrial, que implicaria sacrifícios à classe trabalhadora, restrições econômicas e políticas às oligarquias tradicionais e contrariava os interesses dos industriais de médio porte locais. Para além, na política externa, buscou adotar uma postura independente e aberta às relações com diferentes países, inclusive com a União Soviética, contrariando a ala mais conservadora e os Estados Unidos.

Aliada a isso, a política, em decorrência da maneira como Jânio Quadros exercia o governo, com atitudes imprevisíveis, marcadas por "ziguezagues e incoerências" (REIS FILHO, 2010, p. 325), utilizando-se, por exemplo, dos famosos "bilhetinhos", uma tentativa de suplantar os desmandos políticos e burocráticos da ineficiência e dos interesses tradicionais. Tal posicionamento contrariava as elites e o Congresso, o que levou a União Democrático Nacional (UDN), partido que dava sustentação política ao seu governo, a retirar-lhe o 
apoio. Nessa linha, Jânio Quadros articula como saída para a crise, a renúncia ao cargo de presidente. Confiando mais no seu carisma, não tanto na efetiva autoridade, intentou assegurar um mandato bonapartista-civil, com retorno ao governo por meio da mobilização popular, do respaldo do empresariado e do apoio de uma coalizão militar. A manobra não surtiu o efeito esperado.

A partir daí, os ministros militares: Vice-Almirante Sílvio Heck (Marinha), Marechal Odylio Denys (Guerra) e Brigadeiro do Ar Grun Moss (Aeronáutica), não dispostos a endossar a atitude de uma "figura errática e excêntrica" como a de Jânio Quadros, buscaram articular uma saída que não se concretizasse na posse do vice-presidente eleito, João Marques Melchior Goulart, do Partido Trabalhista Brasileiro (PTB) (DREIFUSS, 1981, p. 129).

Imbuídos desse objetivo, divulgaram um documento, respaldado pela UDN, pelas elites agrária e industrial, pelos interesses multinacionais e associados; para além, pelos militares ligados à Escola Superior de Guerra e pelos políticos tradicionais, em que manifestavam a inconveniência da posse de João Goulart. Defendiam o rompimento da ordem jurídica, para assegurar a convocação de novas eleições presidenciais. Os ministros militares contavam com apoio de setores totalitários e entreguistas, mas não contavam com o apoio popular (TEIXEIRA, 1994).

O contexto mundial demarcava relações conflitivas da Guerra Fria, com incisivo embate ideológico entre as forças políticas vinculadas ao comunismo e ao capitalismo. Isso leva os Estados Unidos a assumir uma "paranóica vigilância", característica marcante da nova política destinada à América Latina, orientada para o fortalecimento dos militares da região, tidos como resistência diante de qualquer iminência revolucionária e também para o desenvolvimento de uma política de ajuda, no intuito de construir uma imagem americana positiva no continente e ampliar sua influência. Essa ofensiva para a América Latina diz respeito à Revolução Cubana, operada por Fidel Castro, que implantou o regime socialista em Cuba e muniu as esquerdas com novos projetos revolucionários. Os interesses estadunidenses não se restringiam a fortalecer governos anticomunistas, visavam também ao crescimento econômico do continente (FICO, 2008, p. 25). Outros desdobramentos da conjuntura mundial contrariavam os americanos, 
para além de Cuba, como a Guerra do Vietnã pela libertação nacional (1959 - 1976), a expansão do maoísmo (movimento influenciado pelo pensamento do líder comunista chinês Mao Tsé Tung).

À luz da realidade brasileira, o período que vai do final da década de 1950, até início da de 1960 é de intensa efervescência política. A emergência de novas forças sociais na vida nacional, os movimentos sociais, as ligas camponesas ficaram fortalecidos. O rápido processo de industrialização, com a introdução do capital estrangeiro e das multinacionais, culminou no crescimento da camada urbana dominada pelos operários da indústria, do setor terciário, pelos trabalhadores braçais e dos serviços públicos, intensificandose a mobilização e a organização dos trabalhadores em sindicatos, na luta por seus direitos.

Em profunda articulação com essa manobra militar, atuaram o Instituto de Pesquisas Econômico-Sociais (IPES) e o Instituto Brasileiro de Ação Democrática (IBAD), entidades anticomunistas que aglutinavam empresários brasileiros ligados aos interesses do capital internacional, políticos, intelectuais, profissionais liberais e militares. Ambas articuladas à Escola Superior de Guerra (ESG), elaboraram diversos estudos relativos às questões nacionais para a formulação de um planejamento estatal. IPES e IBAD apresentavam duas faces, uma, a de contribuir para a solução dos problemas nacionais, promover a educação cultural, moral e cívica do indivíduo; outra, na prática, escancarava a face oculta de articuladora de uma sofisticada campanha política, ideológica e militar, com manipulação de opiniões e guerra psicológica, ao se opor às estruturas populistas, ao executivo nacional-reformista, ao comunismo e às forças sociais populares. Dispunha de grandes somas financeiras para colocar em prática uma ardilosa campanha de conteúdo anticomunista, e em favor da disseminação de valores estadunidenses por meio de programas radiofônicos, de televisão e matérias nos jornais.

Sobre o IPES, afirma Dreifuss (1981, p. 164), “[...] um verdadeiro partido da burguesia" que, por meio de seus intelectuais orgânicos, os técnicos empresários, os tecno-burocratas, articulava os anéis burocráticos empresariais, com objetivo de apresentar demandas de classes a serem convertidas em políticas públicas. 
Na busca por identificar a oposição política de Goiás, Dreifuss (1981) menciona os líderes oposicionistas vinculados à UDN - Emival Caiado e Alfredo Nasser - como pertencentes ao IPES. Apesar disso, as atividades oposicionistas desenvolvidas em Goiás não expressam o caráter orgânico presente em outros estados, em especial Guanabara e São Paulo. Já o IBAD, de maneira mais efetiva em Goiás, aparece em 1962 financiando candidaturas de políticos do PSD e da UDN, para além de manter o programa A Semana em Revista, na Rádio Difusora de Goiânia, dos padres redentoristas, com pregação anticomunista. Nos estudos empreendidos, Souza (2009) não identificou vestígios da presença do IPES em Goiás, tendo em vista a estrutura econômica de pouca representatividade para a fração de classe que se organizava no contexto nacional. No entanto, no programa de governo de Mauro Borges, há convergências com as propostas do IPES, em especial no projeto de modernização do agro, com base na proposta de colonização agrícola, elaborada pelo Escritório Técnico Empresarial do engenheiro Paulo de Assis Ribeiro, destacado membro do IPES/São Paulo e um dos formuladores do Estatuto da Terra, apresentado pelo presidente Marechal Castelo Branco.

Dentro desse cenário, a ascensão de João Goulart, identificado como herdeiro da política populista de Getúlio, de proximidade com a esquerda, expressava uma ameaça aos interesses das forças políticas tradicionais, contrárias à adoção de um programa que contemplasse as demandas populares e de aspirações nacional-reformistas. Sob esse respaldo, os ministros militares, influenciados ainda pelos Estados Unidos, tentam impedir a posse de João Goulart.

Isso leva os governadores do Rio Grande do Sul, Leonel Brizola, e de Goiás, Mauro Borges Teixeira, a convocar o povo brasileiro a defender a Constituição, deflagrando o Movimento pela Legalidade. Sem negar as diferenças ideológicas entre Brizola e Mauro, havia uma linguagem política - a defesa da legalidade - que os unificava, por meio da qual se reconheciam e se valorizavam.

Ao responder o mencionado manifesto dos ministros militares, Brizola foi enfático: “[...] posso garantir que o primeiro tiro a ser disparado não será nosso. No segundo, porém, não erraremos o alvo, pois somos bons atiradores" (FERREIRA, 2011, p. 247). 
Paulatinamente, o movimento começou a ganhar forma e, para viabilizar esse processo, entrou em cena uma rede de apoio à luta, com adesão de diversos segmentos da sociedade, sindicatos, União Nacional dos Estudantes (UNE), Ordem dos Advogados do Brasil (OAB), Confederação Nacional dos Bispos do Brasil (CNBB), artistas, intelectuais, empresários do comércio e da indústria, militares nacionalistas, lideranças políticas. Em diversas partes do país, houve adesão dos movimentos sociais, inclusive de centenas de camponeses da região de Formoso (GO), sob a liderança do Partido Comunista Brasileiro (PCB), que se mostravam dispostos a intervir militarmente no movimento popular em favor da posse de Jango. Contra a posse e a favor dos militares, a figura emblemática do Governador do Estado da Guanabara, Carlos Lacerda (UDN), que impôs a censura e apreensão dos jornais favoráveis à posse de João Goulart e, ainda divulgando falsa informação de que tudo estava na calmaria, tranquilidade e paz social (ABREU, 2006).

O posicionamento de resistência e desobediência dos governadores Brizola e Mauro Borges, ao convocar o país a resistir ao golpe, provoca uma fratura no seio das forças armadas: o Marechal Henrique Lott - companheiro de chapa de João Goulart à presidência da República, apoiado pelo PSD e pelo Partido Comunista, derrotado - defendeu o respeito à Constituição. Nesse entendimento, o III Exército, desobedecendo às ordens do ministro da Guerra, adere ao movimento. Sob o comando do general Machado Lopes, aglutinava as unidades militares do Rio Grande do Sul, Paraná e Santa Catarina, detentoras do maior poderio bélico do país, com mais de 150 mil homens armados. Na compreensão do tenentecoronel do exército e governador Mauro Borges, o III Exército, ao demonstrar ser "[...] fiel intérprete e herdeiro desse passado de glórias, nos dá o dignificante exemplo, recusando-se a compactuar com o golpeamento das instituições" (TEIXEIRA, D. L., 1994, p. 78; ABREU, 2006).

Brizola requisitou os transmissores da Rádio Guaíba (Porto Alegre) para o Palácio Piratini, sede do governo gaúcho, e, por meio das ondas médias e curtas, no dia 28 de agosto de 1961, fez um pronunciamento a todo o país, conclamando o povo a defender a posse do vice-presidente, em conformidade com a constituição vigente. 
Convocou, ainda, todas as emissoras de rádio do país a integrar a Rede da Legalidade, com objetivo de manter a população informada sobre a situação naquele momento de crise. Essa empreitada contava com a participação de jornalistas, radialistas e técnicos de todas as emissoras. No decorrer do movimento, 104 emissoras do país integraram a rede, que incessantemente convocava o povo a lutar pelo cumprimento da Constituição, bem como informava sobre as negociações que se desenrolavam entre o Congresso e os militares. Nos países vizinhos, foram transmitidos boletins dando conta dessa notícia em diferentes idiomas - inglês, espanhol e alemão. A Rede exerceu um papel fundamental para a tomada de posição da população em defesa da continuidade democrática.

Vale ressaltar que o ex-governador Leonel Brizola foi o homem que deu início a essa série de acontecimentos e durante todos os momentos esteve no centro. Ele "[...] unificava as esquerdas, e daí sua ousadia no desafio.” (FERREIRA, 2007, p. 546).

Jornais de circulação nacional, com prestígio e influência sobre os formadores de opinião, ficaram divididos em relação à defesa da Constituição, com a posse de João Goulart. A favor: Jornal do Brasil, Correio Brasiliense e Última Hora; Contrários: Jornal O Globo e O Estado de São Paulo. Esse jornal paulista propunha a convocação das forças armadas para defender o Brasil de um possível golpe operado por forças subversivas (FERREIRA, 2008; ABREU, 2006). Tais posições deixavam em evidência a tensão, refletida também na imprensa, entre as forças políticas daquela conjuntura, marcada pelo acirramento dos ânimos; a defesa ou acusação apresentada por determinado jornal significava demarcar posição política para além dos trâmites partidários.

Em Goiás, o governador Mauro Borges aderiu de imediato ao movimento com a emissora estadual, a Rádio Brasil Central, e solicitou que outras emissoras do estado fizessem o mesmo. "Não sou nem jamais fui comunista”, mas, “[...] se a sucessão não ocorrer dentro do respeito à Constituição, Goiás estará pronto a lutar em defesa da ordem nacional" (TEIXEIRA, 1994, p. 35-50). A condição de filho e herdeiro político de Pedro Ludovico Teixeira, o líder político mais representativo de Goiás, garantia a Mauro Borges a possibilidade de colocar em prática suas propostas. O engajamento 
de Goiás no Movimento da Legalidade teve o aval de seu pai, do PSD e da Assembleia Legislativa de Goiás, ao convocar os deputados em sessão extraordinária e hipotecar apoio a Mauro Borges e ao movimento.

O Palácio das Esmeraldas, sede do governo de Goiás, tornouse o centro do movimento goiano pela legalidade, concentrando todas as ações, decisões, informações. Foi montado um serviço de informação que a todo instante recebia notícias da movimentação em Brasília, Rio Grande do Sul, Rio de Janeiro e outras principais localidades.

Mauro Borges não era um líder nacional, mas em decorrência da adoção de uma gestão planejada, por meio do Plano de Desenvolvimento Econômico, gozava de um reconhecimento que extrapolava o Estado de Goiás; e de modo efetivo contribuíam para isso as conferências proferidas e exposições sobre as realizações do governo, em diferentes cidades do país, aliadas ainda às entrevistas para importantes jornais, como Última Hora, Jornal do Brasil, e para rádios, como a Voz da América. Com tal prática, Mauro Borges intentava atrair investimentos para o estado, bem como buscar legitimidade para seu projeto de modernização de Goiás (RABELO, 2009).

O denominado Plano Mauro Borges tinha como meta instituir mecanismos de aceleração do desenvolvimento em Goiás. Foi considerado arrojado para aquele contexto, com proposituras para a agricultura, pecuária, transportes, comunicação, energia elétrica, turismo, saúde, educação, assistência social, armazenagem, comunicação e reestruturação das atividades administrativas. Essas áreas, conforme afirma João Bernardo (2009), são condições estruturais necessárias à organização do capital, denominadas Condições Gerais de Produção (CGP), demonstrando que a finalidade das políticas públicas, nesse contexto, estava voltada para a promoção do crescimento econômico e da expansão capitalista.

A proposta revelou o perfil de atribuição estatal, então em desenho. No entendimento de Mauro Borges, a função e o papel do estado e da burocracia pública seria promover as mudanças econômicas e sociais em Goiás, assegurando-lhe a inserção ao eixo dinâmico do desenvolvimento brasileiro. Em linhas gerais, a ação estatal seria o lócus privilegiado capaz de promover e disseminar 
as mudanças por toda sociedade. E, ao assegurar condições para a expansão da economia, tornou o poder público indispensável e decisivo nas transformações econômicas do estado. Nesses princípios está centrada a convicção reformadora de Mauro Borges: de transplantar para um estado periférico a experiência de planejamento e desenvolvimentismo, conduzida por uma elite intelectual detentora de conhecimento científico, com prática de tratar as questões políticas e sociais como questões eminentemente técnicas e engajadas em um projeto de reformas que assegurasse a inserção da economia goiana nos marcos do desenvolvimento nacional (FAVARO, 2010).

Mauro Borges, militar de carreira, tenente-coronel graduado pela Escola de Estado-Maior do Exército, nacionalista, mostrava-se obstinado pela ideia de desenvolvimento, de progresso e de modernização. Engajado com as questões do seu tempo, de pensar e reformar Goiás, o planejamento, a tecnocracia e o intervencionismo estatal, alimentaram seus ideais reformadores. Defensor da economia livre e competitiva, intentou, ainda, romper com a política tradicional de influência dos oligarcas.

Diante daquela situação de conflito criada pelos opositores - a posse de João Goulart. Mauro Borges estava convencido da necessidade de formular estratégias para o enfrentamento da "[...] ação antinacional programada pelos conspiradores golpistas" (TEIXEIRA, 2002, p. 216). Detentor de larga experiência em estratégias militares, para o apoio à posse de João Goulart, elaborou um plano tático de forma minuciosa, inclusive com apoio de logística, por temer que outra forma de sucessão presidencial burlasse os princípios constitucionais. Sob esse argumento, propôs o Plano Geral de Ação, com objetivo de assegurar o bem-estar e a ordem cívica do povo de Goiás e do Brasil. No seu entendimento "[...] seria uma humilhação nacional, um aviltamento inominável, se retroagirmos desse caminho (autonomia da política externa) e voltarmos à condição pura e simples de satélite [...] que Deus nos ajude e inspire os condutores do Brasil" (TEIXEIRA, 1994, p. 51). Com diferentes alternativas planejadas, o governador reuniu seu secretariado para detalhar as ações, designar os grupos e seus chefes, demonstrando, assim, toda a habilidade militar quando a ordem é ameaçada. 
À frente do governo de Goiás, Mauro Borges adotou um modelo centralizado de gestão. $\mathrm{Na}$ pesquisa documental e nas entrevistas realizadas com seus ex-assessores, há indícios de certo grau de personalismo do governador, à medida que tudo girava em torno dele. Soube tirar proveitos da situação, ainda que para assegurar sua eleição ao governo houvesse empreendido uma ampla aliança política. Com habilidade, Mauro Borges construiu seu secretariado com diversas forças, no entanto, aglutinou em torno de si fiéis e comprometidos auxiliares, que compartilhavam com ele o poder, sem suprimir a sua força de administrador. Para além, canalizavam apoio político para ele. No Movimento da Legalidade não foi diferente.

O governador de Goiás, por meio dos transmissores da Rádio Brasil Central, fez um pronunciamento à nação:

\begin{abstract}
[...] aceitar uma ditadura militar retrógrada, sem programa, sem rumo [...] será reconhecer em nosso país uma incapacidade congênita que nos privaria do direito de manter relações comerciais e diplomáticas com quem nos convenha [...] com países que tenham regime diferente do nosso para o lado da esquerda, pois para com os da direita não opõem obstáculos esses fariseus da democracia[...] convocamos a resistência, a repulsa aos aventureiros [...] aguardamos as decisões do Congresso [...], pois das atitudes deles dependerá nossa palavra de ordem (TEIXEIRA, 1994, p. 50).
\end{abstract}

Após esse pronunciamento, o Exército censurou a Rádio Brasil Central e mandou lacrar todos os transmissores, censurando, ainda, todo o sistema de comunicação do Estado de Goiás - jornais, correios e telégrafos - para assegurar que as noticias do Movimento da Legalidade não fossem divulgadas. Em desobediência à censura do Exército, a Rádio Brasil Central passou a operar diretamente do Palácio das Esmeraldas, sob o comando de Mauro Borges.

Embora as atitudes e tal pronunciamento tenham apontado para uma relativa independência e desobediência do governador de Goiás, suas práticas institucionais refletiam seu posicionamento de classe, defensor da harmonia e da paz social. As interpretações 
de Mauro Borges traduzem uma visão de mundo de inspiração cristã, na qual impera um ideal de sociedade baseada na cooperação, sem lutas de classes, com predomínio do interesse coletivo sobre o individual, visando à ordem social, traduzida nos objetivos fundamentais constantes na nossa Constituição. Todos cooperando harmoniosamente para o progresso de Goiás e do Brasil. Nesse sentido, há um tom de reprovação aos políticos profissionais, tidos como movidos apenas por interesses menores, contrapondo-se aos ideais nacionalistas do governador de Goiás, expressos em um projeto de sociedade menos desigual e democrática. Defensor das riquezas e instituições nacionais em face dos interesses estrangeiros, no seu entendimento, legalidade democrática e nacionalismo eram processos complementares entre si.

As palavras de Mauro Borges sintetizam quaisquer que tenham sido as motivações mais profundas do seu gesto, não foi um mero rompante sem explicações. É relevante salientar que ele seguiu suas convicções: "[...] eu jamais poderia concordar com a tutela do Brasil por organizações militares e muito menos por ministros militares. Vi com clareza qual seria e foi minha decisão - enfrentar o golpe." (TEIXEIRA, 1994, p. 51). O depoimento de Mauro Borges, um pessedista, pode trazer um elemento revelador, ao estabelecer um diálogo com Hippolito (1985, p. 112): “[...] a posição do partido (o PSD), desde a primeira hora a favor da posse, é mais uma demonstração de sua importância como fiador do equilíbrio político, evitando a vitória de posições radicais (à esquerda e à direita)".

Para além, a atitude de Mauro Borges demarcava outras implicações políticas. Sua candidatura ao governo de Goiás foi muito trabalhada, em razão de não ter uma efetiva militância política no estado. Sua ascensão ao poder ocorreu em um cenário de renovação dos partidos tradicionais - PSD/UDN - e por meio da articulação de diferentes forças políticas em torno de seu governo. Para tanto, foi decisiva a atuação de seu pai, senador Pedro Ludovico Teixeira (PSD), ao investir todo o seu prestígio político na eleição de Mauro Borges. E, na condição de líder político de maior expressão em Goiás, era fundamental dar continuidade a essa dominação, transferindo gradativamente a herança política para seu filho. Como a falta de militância e a pouca experiência política do governador 
Mauro Borges era bastante criticada por seus opositores, tornouse-lhe imperioso fortalecer sua imagem de gestor competente, de homem público comprometido com os interesses de Goiás e do Brasil, o que lhe assegurava legitimidade política.

Desse modo, em Goiás, a partir daquele momento, havia uma determinação legal, e a tarefa seria estabelecer as condições práticas para resistir a um possível golpe das forças armadas e defender os preceitos constitucionais. Por bem, de preferência; ou por mal, se necessário.

Em diversos pontos estratégicos da capital, Goiânia, foram instalados comitês pró-legalidade, com vistas a arregimentar voluntários. Houve grande adesão: professores, funcionários públicos, donas de casa, profissionais liberais, estudantes secundaristas e universitários. Com isso, formou-se o denominado Batalhão Tiradentes, com aproximadamente cinco mil pessoas, imbuídas da intenção de defender a ordem legal e assegurar a posse de João Goulart. Esse batalhão de civis, sob o comando do capitão da Polícia Militar do Estado de Goiás, Brasil Koury, reunia-se diariamente para receber instrução e treinamento militar, de primeiros socorros, defesa pessoal e manejo de armas, na expectativa de um possível confronto armado contra as forças golpistas. Dessa forma, a população passa a viver um clima de expectativa constante, à espera dos inimigos que poderiam atacar a qualquer instante.

Note-se, a formação militar de Mauro Borges moldou-lhe um perfil de administrador, assegurando-lhe princípios de racionalidade e capacidade de planejamento e execução. Essa formação norteou sua ação à frente do governo de Goiás: na adoção de soluções estratégicas em face das diversas crises políticas que marcaram sua gestão; na indicação de militares do exército para assumir postos-chaves em seu governo; na repressão policial aos movimentos camponeses e ações de trabalhadores rurais, organizados com vistas a ocupar terras tidas como particulares; nas estratégias de modernização do agro goiano, por meio dos Combinados Agrourbanos, que inclusive contaram com apoio direto da Academia Militar das Agulhas Negras (ESTEVES, 2011). 
Com efeito, as medidas adotadas para resistir a um possível "golpe de Estado" refletem isso, e mais, em certas medidas, demonstram um demasiado exagero: para surpreender o inimigo, Mauro Borges propôs a Missão Doutor Irineu; sob comando do engenheiro Irineu Borges do Nascimento, secretário de Planejamento, um grupo de homens seguiu para Itumbiara, cidade goiana na fronteira com Minas Gerais, por onde passa a estrada que liga São Paulo a Goiânia. A missão consistia em interromper a estrada por meio de dinamites, com destruição da ponte sobre o Rio Paranaíba, na divisa de Goiás com Minas Gerais. Proposta similar foi idealizada em Cristalina, via de acesso a Brasília. Tudo para impedir qualquer manobra dos inimigos.

No pátio do Palácio das Esmeraldas, foi instalado um gerador, a ser acionado em caso de emergência ou no caso de a Usina de Cachoeira Dourada ser tomada pelo inimigo. Alguns canhões foram instalados sobre a marquise do Palácio e nos prédios vizinhos. Em possível passagem de João Goulart por Goiânia, em direção a Brasília, Mauro Borges determinou construção de pista de pouso clandestina, ao lado da Penitenciária Agrícola do Estado de Goiás. Missão foi realizada pelo Departamento de Estradas e Rodagens, com eficiência. Concluiu o trabalho em três horas. A pista passou a ser fortemente guardada, com destacamentos de policiais e barricadas. $\mathrm{O}$ governador de Goiás colocou o avião do estado à disposição de João Goulart. Outra estratégia planejada e executada foi a apreensão de todas as armas e munições existentes nos estabelecimentos comerciais de Goiânia, colocadas sob custódia do Batalhão Anhanguera da Polícia Militar do Estado de Goiás. A medida obteve apoio dos proprietários e visava a assegurar melhores condições de armamento, em face da precariedade existente no estado. Mauro Borges delegou essa missão ao secretário de Segurança Pública, Rivadávia Xavier Nunes. Em questão de horas, um considerável arsenal de armas era depositado no Palácio das Esmeraldas (TEIXEIRA, 1994).

Em prosseguimento à ofensiva, o presidente da VARIG (Viação Aérea do Rio Grande do Sul) determinou a adaptação de aviões com autonomia para operar entre Porto Alegre e Goiânia, sem escalas, com intuito de transportar armas e munições para o movi- 
mento em Goiás (FERREIRA, 2011). Essa operação demonstra a articulação política entre Mauro Borges e Leonel Brizola.

O posicionamento de Mauro Borges retrata a maneira como ele buscou articular a prática militar com a ação política. Suas práticas institucionais refletiam sua visão de mundo. Mauro Borges deu à condução política o que Lucien Goldmann (1979, p. 20) definiu como visão de mundo, um "[...] conjunto de aspirações, de sentimentos e de ideias que reúne os membros de um grupo e os opõem aos outros grupos". Por meio das estratégias propostas por ele, é possível depreender sua coerência nas decisões políticas tomadas para aquele contexto, com base em sua formação, e do seu lugar de fala, "[...] para garantir a manutenção da democracia e da lei”. (TEIXEIRA, 1994, p. 36). Isso confirma-se, por um lado, na condição de um nacionalista a defender a democracia, a lei e a ordem constitucional; por outro, dentro de um contexto marcado por conflitos de interesses em torno da distribuição e redistribuição de poder, Mauro Borges buscou assegurar uma proeminência política para fortalecer politicamente seu governo e, consequentemente, seu poder.

Mas, afinal, o confronto armado não aconteceu, diz Reis Filho (2010, p. 327): “[...] não houve luta. Na tradição Itararé, ambas as partes recuaram." No dia 29 de agosto, o Congresso Nacional rejeitou o pedido de impedimento apresentado contra a posse do vice-presidente. A partir daí, buscou-se o entendimento entre o Congresso e os militares, na tentativa de uma solução conciliatória para assegurar a posse de João Goulart. Como desdobramento dessas negociações, foi instituído o parlamentarismo, de maneira casuística, reduzindo os poderes presidenciais, por meio da Emenda Constitucional $\mathrm{n}^{\circ} 4$, aprovada às pressas em 2 de setembro de 1961. Argumenta Reis Filho (2010, p. 325-236) que, “[...] se houvessem (os militares) obtido êxito, quem sabe, talvez a ditadura militar começasse com dois anos e meio de antecedência [...]"; e prossegue afirmando, foi imposto "[...] um parlamentarismo híbrido: a um presidente enfraquecido, associava-se um parlamento fraco."

Essa saída conciliatória acirrou os ânimos dos radicais de ambos os lados. A direita argumentava que, num enfrentamento, eles levariam a melhor. A esquerda lamentou a oportunidade perdida 
por João Goulart de infringir uma derrota histórica aos inimigos (REIS FILHO, 2010).

Em Goiás, a repercussão do parlamentarismo não foi diferente. Os aliados de esquerda, capitaneados pelos estudantes, organizaram uma grande manifestação pelas ruas da capital, em repúdio à saída conciliadora. Para o Secretário de Planejamento da gestão maurista, engenheiro Irineu Borges, João Goulart "[...] reinava, mas não governava" (TEIXEIRA, 1994, p. 119).

Feito o acordo entre Congresso e militares, certa tensão pairava em relação à vinda de João Goulart para Brasília. Mas o desenlace caminhava para seu final, nenhum tiro foi dado, ruindo-se o grandioso planejamento de estratégias. Ainda assim, na capital goiana, Mauro Borges convocou todos os voluntários, que tomaram as ruas da cidade, além da Polícia Militar e Exército, que aderiram ao governador para permanecer de prontidão, preparados para o combate, se necessário fosse. Não foi o caso, o confronto não aconteceu.

Por fim, houve uma tentativa de manobra por parte de alguns integrantes da Força Aérea Brasileira para interceptar e abater o avião no qual viajaria Jango - Operação Mosquito - mas foi abortada por subordinados dessa força, que se rebelaram e prenderam os oficiais revoltosos (TEIXEIRA, 1994). Em relação a tal episódio, essa versão é predominante quando o fato é resgatado; no entanto, Amir Labaki (apud ANDRADE, 2011), afirma que a "Operação Mosquito" foi uma estratégia utilizada pela Rede da Legalidade para assegurar que João Goulart chegasse com segurança à capital gaúcha. Tendo em vista todas as inflexões e desdobramentos impostos por aquela conjuntura, com diferentes e conflitantes interesses, articulados a uma disputa pelo poder político, pode-se considerar a tese de estar em curso uma operação de sabotagem ao avião.

Um argumento essencial daquela conjuntura: a defesa da legalidade mobilizou "[...] as forças que paralisaram os golpistas, chamados desde então de gorilas" (REIS FILHO, 2010, p. 328). No final, descontentamentos à parte, João Goulart embarcou para a capital federal sob forte esquema de segurança, para, então, no dia 7 de setembro de 1961, tomar posse como presidente do Brasil (1961-1964), em sessão solene no Congresso Nacional, ao lado de seu primeiro-ministro, o conciliador mineiro Tancredo Neves (PSD). 
No plano nacional, decorrido o fiasco do golpe, as forças que se opuseram à posse de João Goulart desencadeiam uma intensa campanha de desestabilização do seu governo, com aval do governo estadunidense (FICO, 2008).

Em âmbito estadual, vale ressaltar que sempre ocorreu uma acalorada disputa pelo poder em Goiás, envolvendo PSD e UDN, e, não por acaso, esse entrevero instigou a oposição udenista goiana a intensificar seus ataques a Mauro Borges, ressaltando suas ligações com Brizola, com João Goulart e com o comunismo. Entretanto, o Movimento da Legalidade ampliou o prestígio político do governador junto aos goianos, projetou seu nome nacionalmente, como resultado dessa bem sucedida experiência democrática. Deu mostras de que Goiás dos coronéis estava ficando um pouco mais distante, ao injetar fôlego novo ao seu governo, com respaldo político para as ações, sobretudo as inovações da administração racionalizadora, e, consequentemente, prestígio político. Além do mais, o protagonismo de Mauro Borges diante de um acontecimento nacional como o Movimento da Legalidade lhe assegurava legitimidade e autonomia política, inclusive para sair da tutela política de Pedro Ludovico, distanciando-se da política tradicional, do mandonismo dos oligarcas, deixando de ser sombra para caminhar com as próprias pernas e alçar voos maiores. Conforme afirma Rabelo, "Mauro [...] ambicionava [...] sua indicação para disputar a vice-presidência da República em 1965” (RABELO, 1978, p. 106).

Fica claro, portanto, que Mauro Borges contava com apoio popular, tanto na mobilização em torno do Movimento pela Legalidade quanto na disposição em resistir ao Golpe em Goiás.

Entretanto, no entendimento de Rabelo (2009), Mauro Borges não pode ser definido como um líder de massas. Situado dentro da política tradicional de Goiás, onde os líderes políticos se restringem a uma região, com resquícios das práticas dos coronéis, Mauro Borges foi eleito deputado federal (PSD) mais votado de Goiás (1958) e governador (1960), sem nenhuma militância política, numa demonstração da força de Pedro Ludovico. À frente do governo, conquistou liderança com as práticas institucionais inovadoras levadas a cabo. De fato, sua emergência como líder ocorreu a partir do Manifesto à Nação, na defesa intransigente do cumprimento constitucional e da 
posse de João Goulart. Seu gesto teve excelente repercussão, assegurando seu reconhecimento como líder verdadeiro. Assim, não é o aspecto ideológico que fomenta a relação líder-massa. $\mathrm{O}$ alcance do gesto de Mauro Borges não é apreendido por todos, mas por estudantes, lideranças políticas, intelectuais. Vai tornar-se determinante na relação líder-massa, portanto, ao atingir as camadas populares, com a imagem de um líder de projeção nacional. Representação fiel do homem da legalidade, o soldado da democracia, o inimigo do atraso, o governador honesto.

Tanto quanto se pode inferir, os passos dados por Mauro Borges conferiram-lhe a condição de um líder populista, mas é importante destacar que ele se diferenciava dos líderes populistas clássicos pela relação estabelecida com as camadas populares. Suas estratégias não tinham um fundo ideológico que o aproximasse dos demais líderes populistas do país, nem o apelo emocional às massas. As práticas populistas de Mauro Borges concretizavam-se taticamente como apoio ao Plano de Desenvolvimento Econômico, visando à adesão às suas obras.

Outro grande momento do protagonismo político nacional de Mauro Borges naquela conjuntura da Guerra Fria foi quando da sua participação, em 1961, na criação da Frente de Libertação Nacional, juntamente com Leonel Brizola, Miguel Arraes, os deputados Francisco Julião e Barbosa Lima Sobrinho, o Presidente da União Nacional dos estudantes - Aldo Arantes, o secretário do Movimento Nacionalista Brasileiro - coronel Oscar Gonçalves, dentre muitos outros. Dentre os pontos defendidos estava a proposta da nacionalização das empresas estrangeiras, a efetivação da reforma agrária, o controle sobre a remessa de lucros para o exterior. O Manifesto de Goiânia marcou o lançamento da Frente e reafirmou o viés nacionalista do movimento: "[...] não seremos colônia dos EUA, nem satélite da URSS".

$\mathrm{Na}$ verdade, esse movimento aglutinava diferentes posições políticas, não tinha em si mesmo uma conotação classista. O discurso nacionalista adotado, porém, assumia significados e traduções diferentes, podendo ser vinculado "[...] ao discurso político de classes antagônicas que dele fariam leitura e apropriações distintas" (PESSANHA; MOREL, 2010, p. 313). Cumprida a meta de assegurar a 
eleição de uma significativa bancada de parlamentares nacionalistas, a Frente foi extinta logo após o término do processo eleitoral.

Com a ruptura da aliança PSD/PTB, a mudança no que se refere ao nacional-desenvolvimentismo, que "[...] assumiria dimensão diversa daquela adotada até então como resultante das ligações de Mauro Borges com o grupo nacionalista radical" (RABELO, 2009 p. 68), leva o governador paulatinamente a distanciar-se da postura democrática que assumiu em 1961, e do governo federal, alegando a falta de apoio de João Goulart. O governo de Goiás tinha plano de construir uma grande Usina Metalúrgica de Níquel em Niquelândia, o que esbarrava nos interesses do grupo Votorantim, sob o comando do Senador José Ermírio de Morais (PTB), detentor da concessão da exploração da jazida de níquel situada naquela localidade, cujo prazo da concessão estava vencido, sem ter ocorrido nenhuma exploração e prospecção. Mauro Borges demonstrou o interesse de Goiás na exploração da jazida e solicitou providências de João Goulart quanto a essa irregularidade do citado grupo, sem que fosse atendido. Conforme afirma o governador de Goiás, nenhuma providência foi tomada, para não contrariar os interesses do Senador José Ermírio de Morais (TEIXEIRA, 2006). Há indícios de que, aliados a essa questão, a inexistência de uma participação efetiva de representantes do Estado de Goiás no governo federal e o restrito apoio financeiro da União distanciaram o governo maurista de João Goulart.

Tais impasses não foram superados. E, com o passar do tempo, outros fatores contextuais corroboraram para a insatisfação de Mauro Borges em relação ao governo federal, culminando no lançamento do Manifesto à Nação, em 31 de março de 1964, ao condenar a possível continuidade do Presidente João Goulart, conforme escrito neste documento:

[...] será a solução destruir o regime democrático e levantar a bandeira da República Popular do Brasil? [...] afirmo que não $[\ldots]$ precisamos de um governo com autoridade, forte [...]. É preciso que não se permita ao Presidente João Goulart o uso das ditas reformas para seu continuísmo [...] aspiramos e lutaremos por um governo social economicamente justo, 
calcado em princípios cristãos. Queremos as reformas dentro da lei, queremos governo que ao lado da iniciativa privada, socialmente justa, e com um planejamento global, dinamize todas as potencialidades de trabalho e riqueza, para que aumente a produção e distribua com equidade os seus frutos.

A instalação de um governo comunista no Brasil era também condenada por Mauro Borges, assumidamente um anticomunista:

[...] existem, no Brasil, duas correntes radicalizantes, contra as quais me oponho em nome de uma democracia dinâmica e socialmente justa: a comunista e a lacerdista. Minha posição só pode ser confundida pelos inimigos dos interesses nacionais. Luto por uma democracia brasileira, com autoridade forte e definida, sem totalitarismo, planificada, autêntica e cristã (REVISTA MANCHETE, 1964, p. 21).

Com esses argumentos, estava posta aí a explicação de Mauro Borges para o apoio ao golpe civil militar orquestrado pelas Forças Armadas brasileiras e, consequentemente, à deposição de João Goulart do cargo de Presidente do Brasil. Disso resultou sua participação na reunião do Rio de Janeiro, no início de abril desse mesmo ano, com a presença dos governadores Carlos Lacerda (RJ), Magalhães Pinto (MG), Adhemar de Barros (SP) e Nei Braga (PR), com objetivo de referendar o nome do Marechal Humberto de Alencar Castelo Branco, indicado para assumir a Presidência da República. Mauro Borges foi aluno de Castelo Branco na Escola Superior de Guerra, por quem tinha profundo respeito e admiração. A indicação de Castelo Branco foi articulada por um grupo de generais ligados à Escola Superior de Guerra (ESG), liderados por Golbery do Couto e Silva. Mauro Borges assumiu, em Goiás, a direção das forças revolucionárias, a contragosto da UDN goiana, mas com apoio de Castelo Branco. A indicação do nome de Castelo Branco contrariou os interesses dos generais linha dura, ligados à Escola Superior de Aperfeiçoamento de Oficiais (ESAO), dentre os quais o General Arthur da Costa e Silva, interessado em ocupar o cargo de Presidente da República; preterido, apodera-se do Ministério da Guerra. 
Ainda que Mauro Borges tenha adotado uma postura democrática e bastante expressiva ao defender a posse João Goulart, seu posicionamento político ao lançar o Manifesto à Nação em 1964, em favor do golpe, mobilizando as polícias militar e civil do Estado de Goiás, não pode ser interpretado como uma traição, porque ele sempre fizera parte de uma elite, militar, anticomunista. Sua trajetória política estava vinculada a uma memória familiar que se aproxima da história da região pela saga de Pedro Ludovico Teixeira, uma memória consagrada pela historiografia e pela memória coletiva. Esse legado, o passado de glórias do ludoviquismo, entrelaçado à revolução de 1930, à criação de Goiânia, fortalecia Mauro Borges. Entretanto, esse legado não vem descolado da ferrenha disputa política com o caiadismo, o udenismo, pelo poder em Goiás; estende-se ao governo de Mauro Borges e influencia sua deposição do poder (SANDES, 2002; BARRETO, 2002).

Seu partido, o PSD, uma agremiação partidária de posições conservadoras, com alguns pessedistas adeptos das práticas clientelistas e das cotas pessoais. Não é por acaso a afirmação de Rabelo (2004, p. 50) em relação a esse partido, "[...] comprometido com os interesses dos fazendeiros do interior, ou seja, com os chefes políticos locais", sob o aval de Pedro Ludovico Teixeira, que o comandava de modo caudilhesco. Indo mais além, Mauro Borges, na condição de líder político, adotou um discurso contra a política tradicional, em favor do desenvolvimento, do progresso e da modernização; na prática, todavia, mostrou se à vontade ao usar da força e da repressão contra o movimento camponês na luta por um pedaço de terra. $\mathrm{O}$ moderno, pois, não estava dissociado do atraso (ESTEVES, 2011). No depoimento de Mauro Borges, ficam explícitas as práticas institucionais truculentas utilizadas contra o movimento camponês ${ }^{1}$ :

[...] as agitações rurais encontradas em curso por meu governo e proteladas em suas soluções por administrações passadas, e outras promovidas por elementos suspeitos para tumultuar a vida do Estado, como em Trombas, Formoso, Porangatu, Juçara, Salobrinha, Itaporã, Canuana, Gurupi e Almas, foram energicamente debeladas, estabelecendo-se por vias legais e atendendo a princípios sociais, a verdadeira paz social na maioria da localidade mencionada (2006, p. 48). 
A provável guinada de Mauro Borges para a direita não lhe assegurou uma posição confortável junto aos militares golpistas e seus aliados civis, nem garantia de estabilidade política para seu governo, muito pelo contrário. Foi apeado do poder por essas forças em 26 de novembro de 1964.

Sem dúvida, o Governador Mauro Borges enfrentou todas as inflexões e desdobramentos impostos por aquela conjuntura, com diferentes e conflitantes interesses sociais, articulados a uma disputa pela hegemonia militar do Estado. Nas argumentações de Souza (2009), essa disputa pela hegemonia militar do Estado conquistou aliados em frações da classe dominante, articulada na defesa dos interesses corporativos. Destaque para as elites agrárias, já descontentes por terem seus interesses contrariados e com a expansão das associações e dos sindicatos camponeses em todo o país. Daí, os latifundiários começaram a se organizar em torno de entidades classistas, patronais e atuaram decisivamente para o golpe. Bem articulados nacionalmente, opuseram-se ao Estatuto da Terra proposto por Castelo Branco e se aproximaram dos generais linha dura.

Esse cenário ecoou em Goiás, sendo arquitetada pelos generais linha dura e seus aliados civis goianos, uma ferrenha campanha contra Mauro Borges, com adoção de Inquéritos Policiais Militares, na tentativa de forçá-lo a renunciar ou a demitir todos os seus auxiliares supostamente vinculados ao comunismo. Isso leva Mauro Borges, temendo as intenções dos militares, a se resguardar com um habeas corpus, impetrado pelo jurista Sobral Pinto no Supremo Tribunal Federal, aprovado por unanimidade, fato que despertou ainda mais a ira de seus opositores.

Para um melhor entendimento, as condições objetivas postas por aquela conjuntura eram favoráveis aos inimigos políticos de Mauro Borges, os udenistas. Conforme Souza (2009), justificavase assim, a intensificação dos ataques ao seu governo, ao acusá-lo de manter comunistas no seu secretariado, de ser benevolente com o movimento camponês e de manter ligações com Brizola e João Goulart. Nessa direção, o governador da Guanabara Carlos Lacerda (1960-1965/UDN) veio a Goiânia hipotecar apoio aos udenistas na campanha contra Mauro Borges, utilizando, inclusive, a imprensa nacional para proferir acusações contra o governador de Goiás. Diante de um cenário favorável, estrategicamente, a UDN e as classes 
produtoras goianas, assim como ocorria nacionalmente, aproximamse dos generais linha dura, visando à ascensão ao poder em Goiás, com a destituição do governador Mauro Borges. Ressalta-se que, pelo poder do voto, a tentativa udenista era sempre frustrada em decorrência da estrutura partidária do PSD.

A articulação empreendida pelos generais linha dura e endossada pelos udenistas goianos tinha como alvo principal conquistar a hegemonia militar do Estado, e a intervenção em Goiás significava condição sine qua non para atingir tal objetivo. Castelo Branco justificou lançar mão desse mecanismo, o Golpe em Goiás, como tentativa de conter os ânimos de tais militares e evitar uma radicalização que pudesse levar Mauro Borges a resistir, conforme era seu desejo, com consequências sangrentas, pois contava com o apoio das forças populares. Em frente do Palácio das Esmeraldas, sede do governo goiano, havia em torno de duas mil pessoas, quase que diariamente, esperando as ordens de Mauro Borges, dispostas a pegar em armas para defender o governador e sua permanência no cargo. Não foi o caso. Mauro Borges não conseguiu arregimentar armas e munições suficientes, tendo em vista que os linhas duras fecharam as fronteiras de acesso a Goiás. O Golpe estava em marcha.

\title{
Movement of Legality (1961): Rescuing Mauro Borges' Leadership
}

\begin{abstract}
This communication aims at rescuing the leadership of Governor Mauro Borges in the Movement of Legality. With the resignation of Jânio Quadros in 1961, the military ministers tried to prevent the taking up office of João Goulart, which triggered a broad mobilization in and outside the Congress, in order to ensure the Constitutional order. Initially, two governors - Mauro Borges (GO) and Leonel Brizola (RS) - rose against the coup and put themselves in their states, willing to resist peacefully and militarily up to extremes to defend the Constitution. This spark leads to the Movement of Legality. The participation of Mauro Borges was significant, with extensive experience in military strategies he devised a detailed plan and tactics, including logistics, foreseeing the possibility of an armed confrontation against the coup forces. Face to pressures, as a conciliatory way, is set up a parliamentary, and Goulart took office as president of Brazil (1961). However, political developments take Mauro Borges to support the coup that overthrew Goulart from power in 1964.
\end{abstract}

Keywords: Coup. Military. Strength. Legality. Democracy. 


\section{Notas}

${ }^{1}$ Em relação à política agrária adotada pela gestão maurista dentro de um contexto de forte mobilização e organização dos camponeses, com destaque para Trombas e Formoso (GO), é possível depreender que, se por um lado, foram entregues títulos de propriedade de terra para os camponeses. Isso ocorreu em razão da luta e da pressão deles, por outro lado, essa gestão realizou uma ampla massificação dos sindicatos e da sindicalização dos trabalhadores rurais, como forma de tutela, o que contribuiu para desmobilizá-los, recusando a condição desses espaços de lutas de classe e buscando estabelecer a harmonia e a paz social entre governo, patrões e trabalhadores, como forma de combater o comunismo.

\section{Referências}

ABREU, Alzira Alves de. 1964: a imprensa ajudou a derrubar o governo Goulart. In: FERREIRA. Marieta de Moraes. João Goulart. entre a história e a memória. Rio de Janeiro: Ed. FGV, 2006, p. 107-128.

ANDRADE, Francis W. de B. O aspecto anticomunista da conjuntura politica do periodo pré-1964. Disponível em: http://www.ichs.ufop.br/memorial. Acesso em: 28 de maio 2011.

BARRETO, Roseli de Fátima Brito Netto. Estratégias de Memória: a criação do museu Pedro Ludovico. In: SANDES, Noé Freire. (Org.). Memória e região. Brasília: Ministério da Integração Nacional: UFG, 2002, p. 63-100, (Coleção Centro-Oeste de Estudos e Pesquisas, 11).

BERNARDO, João. Economia dos Conflitos Sociais. 2. ed. São Paulo: Expressão Popular, 2009.

DREIFUSS, Renée Armand. A conquista do Estado. Rio de Janeiro: Vozes, 1981.

ESTEVES, Carlos Leandro da Silva. Estado e agricultura em Goiás: escritórios privados de consultoria e políticas públicas no Governo Mauro Borges (1961 - 1964). Tese (Doutorado) Programa de Pós-Graduação em História da Universidade Federal Fluminense. Niterói, 2011.

FAVARO, Tereza Cristina Pires Favaro. Tecnocracia e Planejamento no Governo Mauro Borges $(1961$ - 1964). VI Simpósio Nacional Estado e Poder: Cultura. Núcleo de Pesquisas sobre Estado e Poder no Brasil (UFF) e os Grupos de Pesquisa História Intelectual e das Ideias (UFS) e História do Tempo Presente (UFS). Universidade Federal de Sergipe. Aracaju, out. 2010. 
FERREIRA, J. Jorge. João Goulart: uma biografia. Rio de Janeiro: Civilização Brasileira, 2011.

Leonel Brizola. Os nacional-revolucinários e a Frente Popular de Mobilização Popular. In: FERREIRA, Jorge; REIS FILHO, Daniel Aarão (Orgs.). Nacionalismo e reformismo radical (1945 - 1964). Rio de Janeiro: Civilização Brasileira, 2007 , p. $543-583$.

FERREIRA, Marieta de Moraes (Coord.). João Goulart. entre a memória e a história. Rio de Janeiro: Editora FGV, 2008.

FICO, Carlos. O Grande Irmão: da operação Brother Sam aos anos de chumbo, o governo dos EUA e a ditadura militar brasileira. Rio de Janeiro: Civilização Brasileira, 2008.

GOLDMANN, Lucien. Dialética e cultura. Rio de Janeiro: Paz e Terra, 1979.

HIPPOLITO, Lúcia P. De raposas e reformistas: o PSD e a experiência democrática brasileira (1945 - 64). Rio de Janeiro: Paz e Terra, 1985.

LABAKI, Amir. 1961: A crise da renúncia e a solução do parlamentarista. São Paulo: Brasiliense, 1986.

MELO FILHO, Murilo; BARROS, Túlio; NEVES, Jader. Goiás a hora da decisão. Revista Manchete. Rio de Janeiro: Bloch editores. Ano 12, n. 658, p. 14-21.

MONIZ BANDEIRA, Luiz Alberto. O governo João Goulart. as lutas sociais no Brasil: 1961-1964. Rio de Janeiro: Civilização Brasileira, 1977.

PESSANHA, Elina G. da Fonte; MOREL, Regina Lúcia M. Classe trabalhadora e populismo: reflexões a partir de duas trajetórias sindicais no Rio de Janeiro. In: FERREIRA, Jorge. O Populismo e sua história: debate e crítica. 2. ed. Rio de Janeiro: Civilização Brasileira, 2010, p. 273-317.

RABELO, Francisco Chagas E. Mobilização social e tradicionalismo político (Governo Mauro Borges, 1961-1964). In: Goiás: Sociedade e Estado. Dalva Borges Souza. 2. ed. Goiânia: Cânone Editorial, 2009, p. 49-84.

Governo Mauro Borges: Tradicionalismo, Planejamento e Mobilização Social em Goiás. Dissertação (Mestrado) - Departamento de Ciência Política/UFMG, Belo Horizonte, 1978.

REIS FILHO, Daniel Aarão. O Colapso do colapso do populismo ou a propósito de uma herança maldita. In: FERREIRA, Jorge. O Populismo e sua história: debate e crítica. 2. ed. Rio de Janeiro: Civilização Brasileira, 2010, p. 319-377.

SANDES, Noé Freire (Org.). Memória e região. Brasília: Ministério da Integração Nacional: UFG, p.17-36, 2002. (Coleção Centro-Oeste de Estudos e Pesquisas, 11). 
SOUZA, Dalva Borges. O Golpe em Goiás. In: Goiás: Sociedade e Estado. Dalva Borges Souza (Org.). 2. ed. Goiânia: Cânone Editorial, 2009. p. 85 -130.

TEIXEIRA, Dulce Loyola. Mauro Borges e a crise político-militar de 1961 em Goiás. Movimento da Legalidade. Brasília: Senado Federal. Centro gráfico, 1994.

TEIXEIRA, Mauro Borges. Tempos idos e vividos. Minhas experiências. Goiânia: Ed. do Autor, 2002. Vieira, 2006. . O Golpe em Goiás: História de uma grande traição. 2. ed. Goiânia: UCG;

\section{Fontes consultadas}

Fundo Mauro Borges. Instituto de Pesquisas e Estudos Históricos do Brasil Central (IPEHBC/PUC/GO)

Manifesto de Goiânia. Frente de Libertação Nacional, Goiânia, 1961 (mimeo). Manifesto à Nação. Goiânia, 31 de março de 1964, (mimeo).

Recebido em 18/01/2012.

Aprovado em 14/02/2012. 